\title{
Customer Loyalty Assessment
}

\section{A Case Study in MADDIRAN, the Distributor of LG Electronics in Iran}

\author{
Ali Dehghan \\ School of Industrial Engineering, University of Oklahoma, USA \\ Tel: 1-734-277-4914Ｅ-mail: ali.dehghan3@gmail.com \\ Arash Shahin \\ Department of Management, University of Isfahan \\ Hezar Jarib St., Isfahan 81746-73441, Iran \\ Tel: 98-311-793-2040_E-mail: arashshahin@hotmail.com
}

\begin{abstract}
The present study attempts to contribute to the knowledge of how customer loyalty could be assessed, using survey questionnaire. After literature review and demonstration of customer loyalty concepts, a comprehensive questionnaire has been developed. A sample of customers from MADDIRAN, the distributor of the LG Electronics in Iran has been taken for study. Statistical measures and analysis such as descriptive, t-test and correlation have been used. The results imply that the proposed questionnaire could be used for recognizing categories of service loyalty, e.g. loyalty, latent loyalty, spurious loyalty and no loyalty. Some questions have been found as inter-correlated.
\end{abstract}

Keywords: Customer loyalty, Questionnaire, Assessment, MADDIRAN, LG Electronics, Iran 


\section{Introduction}

Loyalty has over the past decade become a crucial construct in marketing, and particularly in the burgeoning field of customer relationship management (Ball et al., 2004; Soderlund, 2006). Such loyalty might be to a brand, product, or service outlet. Loyalty is likely to lead to positive attitudes and behaviors such as repeat patronage and purchases, and positive recommendations which may influence other actual or potential customers. A loyal customer base can be a valuable asset for any organization. It reduces the need to seek new customers and is positive feedback that the organization's products and services are meeting the needs of a particular group of people (Rowley and Dawes, 1999). At a very general level, loyalty is something that consumers may exhibit to brands, services, stores, product categories (e.g. cigarettes), and activities (e.g. swimming). Some people use the term customer loyalty as opposed to brand loyalty; this is to emphasize that loyalty is a feature of people, rather than something inherent in brands. Unfortunately, there is no universally agreed definition (Jacoby and Chestnut, 1978; Dick and Basu, 1994; Oliver, 1999; Gee et al., 2008).

As competition intensified during the current economic crisis, many firms are developing or improving their loyalty programs to deter customers defecting to their competitors (Ho et al., 2009). A consensus is emerging that customer loyalty is vital to service business performance. In particular, a loyal customer base will generate more predictable sales, steady cash flow and an improved profit stream (Aaker, 1991a). Accordingly, an increasing amount of attention has been placed by researchers on investigation into customer loyalty to a service provider.

There are two aims of customer loyalty programs. One is to increase sales revenues by raising purchase/usage levels, and/or increasing the range of products bought from the supplier. A second aim is more defensive - by building a closer bond between the brand and current customers it is hoped to maintain the current customer base. The popularity of these programs is based on the argument that profits can be increased significantly by achieving either of these aims (Uncles et al., 2003).

In parallel with the development in quality, researchers and managers have become interested in strong brand names which has driven companies to reconsider the importance of established brands (Aaker, 1991b). The motivation for the increased emphasis on brand names and quality is that they both have a strong effect on customer loyalty (Smith and Whan Park, 1992).

Previous loyalty research has heavily focused on the "satisfaction leads to loyalty" paradigm Baumann et al., 2011) and they rarely provide a unique questionnaire for assessment of customer loyalty.

The purpose of this paper is twofold: first, definitions of customer loyalty are reviewed. Second, literature on customer loyalty questionnaires is studied and a comprehensive questionnaire is proposed, which is then used in a case study in MADDIRAN, the Distributor of LG Electronics in Iran. 


\section{Satisfaction and loyalty}

Customer satisfaction or dissatisfaction is a well-known and established concept in several sciences. Customer satisfaction cannot be evaluated directly using an objective measure. If, however, customer satisfaction is treated as an abstract and theoretical phenomenon, it can be measured as a weighted average of multiple indicators. Customer satisfaction is influenced by two factors: expectations and experienced service performance (Shahin, 2006). Perceived performance is influenced by the consumers' perception of service quality, marketing mix, brand name and image of the company.

Frequently, a high positive correlation between the constructs of satisfaction and quality and product loyalty is reported.

\subsection{The concept of customer loyalty}

Customer loyalty has been largely treated by researchers as either repurchase behavior (e.g. Winner et al., 1998; Loveman, 1998; Soderlund, 1998) or repurchase behavior combined with an attitudinal component (e.g. Dick and Basu, 1994; Andreassen and Lindestad, 1998; Oliver, 1997; de Ruyter et al., 1998; Lemmink and Mattsson, 1998; Griffin, 1995; Price and Arnould, 1999).

Consumer loyalty is considered as an important key to organizational success and profitability (Oliver, 1997; Divett et al., 2003). Those consumers that demonstrate the greatest levels of loyalty toward the product or service activity tend to repurchase more often, and spend more money. As a result, a great deal of research attention has focused on the identification of effective methods of actively enhancing loyalty, including loyalty programs such as point reward schemes (Lach, 2000). In contrast to these reward schemes, several researchers have argued that "customer loyalty can be increased by encouraging consumers to complain" (Fornell and Wenerfelt, 1987, p. 344).

The evolution of the loyalty concept is illustrated in Figure 1. The concept of loyalty first appeared in the 1940s. Two separate loyalty concepts evolved. Namely, "brand preference" (Guest, 1955) which was later referred to as attitudinal loyalty and "share of market" (Cunningham, 1956), which was later referred to as behavioral loyalty. Nearly 30 years after loyalty first appeared in the academic literature, researchers proposed that loyalty may be more complex and that it may comprise both attitudinal and behavioral loyalty. This bi-dimensional concept has since been combined and referred to as composite loyalty. The composite definition of loyalty has become the basis for much loyalty research that has since been undertaken (e.g. Bennett, 2001). The composite definition of loyalty considers that loyalty should always comprise favorable attitudes; intentions and repeat-purchase (Jacoby and Chestnut, 1978). Mandhachitara and Poolthong (2011) believe that the combinational method involving both attitudes and behavior is the most robust and appropriate as it captures the two major influences of consumer decision making.

Table 1 categorizes key measures that have been proposed in the loyalty literature as either 
attitudinal or behavioral. This is by no means an exhaustive summary of loyalty measures. Jacoby and Chestnut's (1978) review of the loyalty literature revealed over 80 loyalty measures proposed by various researchers.

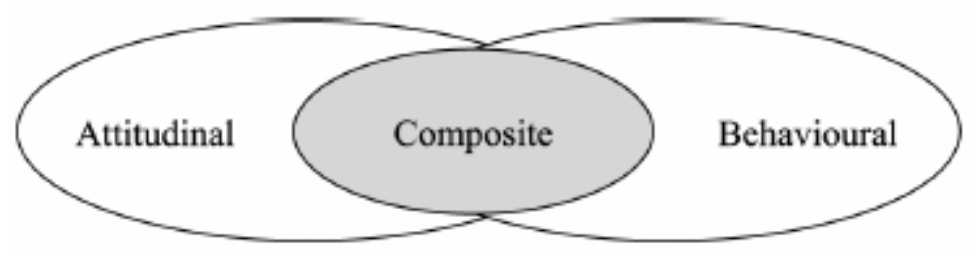

Figure 1. The loyalty construct - 1950-1990 (Rundle-Thiele, 2005)

Table 1. Loyalty measures and their concepts (Rundle-Thiele and Mackay, 2001)

\begin{tabular}{|l|l|}
\hline \multicolumn{1}{|c|}{ Attitudinal loyalty } & \multicolumn{1}{|c|}{ Behavioral loyalty } \\
\hline Attitude toward the loyal/dis-loyal act (sharp & Market share loyalty (Cunningham, 1956) \\
et al., 1997) & also referred to as preferential purchase brand \\
Brand preference (Guest, 1955) & allegiance \\
Commitment (Hawkes, 1994) or attitude & Exclusive purchase (Jacoby and Chestnut, \\
toward the brand measures (Sharp et al., & 1978) \\
1997) & Elasticity's (Sharp et al., 1997) \\
Probability of purchase (Danenberg and & Price until switching (Pessemier, 1960) \\
Sharp, 1996; Jacoby and Chestnut, 1978) & \\
\hline
\end{tabular}

The ability of an organization to attract and retain customers is vital to its success (Ramanathan and Ramanathan, 2011). Often, customers are retained for long periods but without a genuine relationship ever being developed. In addition, Barnes (1997) acknowledges that a customer may not purchase frequently from a firm, even though he or she may feel something of a relationship toward that firm. There may be many other reasons for lack of visitation. Further, this problem of spurious loyalty is not alleviated by the alternative approach of adding attitudinal components to repurchase behavior. Researchers such as Blodgett et al. (1997) distinguish loyalty as a psychological outcome and repurchase intentions as a behavioral outcome. A psychologically loyal customer may not intend to purchase from a service provider because their circumstances prevent them (Barnes, 1997). Kingstrom (1983) has argued strongly loyalty to be treated as a psychological construct. Further, in an interesting development, Oliver (1999) extends the notion of incorporating repeat purchase with loyalty by suggesting that psychological strategies are needed to achieve ultimate loyalty. Excluding repeat purchase, four dimensions of loyalty can be distinguished in the services literature. These dimensions are:

(1) positive word-of-mouth;

(2) a resistance to switch;

(3) identifying with the service; and

(4) a preference for a particular service provider. 
Positive word-of-mouth is a common approach to loyalty conceptualization. Loyal customers become an advocate for the service (Payne, 1993). Four variations of the advocacy concept can be identified:

(1) Providing positive word-of-mouth (e.g. Zeithami et al., 1996; Andreassen and Lindestad, 1998);

(2) Recommending the service to others (Stum and Thiry, 1991);

(3) Encouraging others to use the service (Kingstrom, 1983; Bettencourt and Brown, 1997); and

(4) Defending the service provider's virtues has been proposed by Kingstrom (1983).

Dick and Basu (1994) have developed a framework for customer loyalty that combines both attitudinal and behavioral measures. The authors propose that loyalty is determined by a combination of repeat purchase levels and relative attitude. Relative attitude is determined by attitude strength and attitudinal differentiation. Figure 2 illustrates the loyalty conditions proposed by Dick and Basu (1994). Loyalty, with its high repeat patronage and high relative attitude, would obviously be the ultimate goal for marketers. Raj (1985) found that firms with large market shares also have larger groups of loyal consumers. Loyal customers are less motivated to search for alternatives, are more resistant to counter-persuasion from other brands, and are more likely to pass along positive word-of-mouth communication about the service to other consumers (Dick and Basu, 1994).

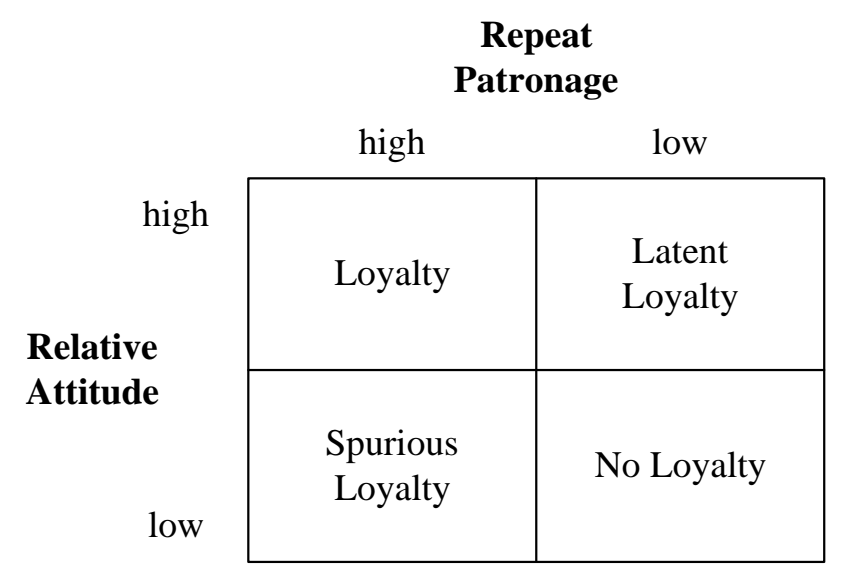

Figure 2. Service loyalty classification scheme (Javalgi and Moberg, 1997; Dick and Basu, 1994)

Latent loyalty exists when a consumer has a strong preference for or attitude toward a company's brand over its competitors' brands, but does not exhibit high repeat patronage due to situational or environmental variable. For instance, a consumer may have a strong attitude about a particular Italian restaurant, but may not frequently visit that restaurant because of a desire for variety in meals or a lack of discretionary income that limits the amount of times that he/she can eat out at a restaurant.

Spurious loyalty occurs when a consumer frequently purchases a brand, but sees no significant differences among brands. This could occur if there were no alternatives in a 
category or if choice is made strictly on past experiences and habits.

Finally, no loyalty exists in a category when consumers see few differences between alternative brands and there are low repeat purchases. Brand switching is common and choice among brands is usually made based on some situational factor, such as the brand that is on sale or that is noticed in an end-of-aisle display.

This classification system can be useful to marketers as they try to build or retain loyalty. Once marketers of services have identified the type of loyalty most associated with their brand, strategies can be implemented that are appropriate for building loyalty under conditions that exist for that service.

\section{Relationship between customer loyalty and customer satisfaction}

Customer loyalty expresses an intended behavior towards the service or the company. This includes the likelihood of future renewal of service contracts or the probability of a change in patronage. Customers may be loyal due to high switching barriers or due to lack of real alternatives. If real alternatives exist or switching barriers are low, management discovers the organization's inability to satisfy its customers via two feedback mechanisms: exit and voice. Exit implies that the customer stops buying the agent's services while voice is customer complaints expressing their dissatisfaction directly to the agent. Customers' exit or change of patronage will have an impact on the long-term revenue of the agent. Effects caused from changes in the retention rate are exponential (not linear) with regard to effects on long-term revenue. Even a marginal reduction/increase in retention rate has significant effects on future revenue (Andreassen, 1995). Customers may also be loyal because they are satisfied and thus want to continue the relationship. History has proved that most barriers to exit are limited with regard to durability; companies tend to consider customer satisfaction as the only viable strategy to keep existing customers. Several authors have found a positive correlation between customer satisfaction and loyalty (Anderson and Sullivan, 1993; Fornell, 1992).

Fornell (1992) examined 27 different businesses and found strong correlations between satisfaction and loyalty. Fornell further found that loyal customers are not necessarily satisfied, but satisfied customers tend to be loyal customers. Highly satisfied customers are much more loyal than satisfied customers and any drop in total satisfaction results in a major drop in loyalty. Xerox conducted a study for satisfaction using a five-point scale from 5 (highly satisfied) to 1 (highly dissatisfied). The relationship between the scores and actual loyalty differed greatly. Customers giving Xerox five were six times more likely to repurchase Xerox equipment than those giving four (Reichheld, 1996). This relationship is illustrated in Figure 3.

During the past decades both marketing academics and practitioners have been intrigued by the relationship between satisfaction and loyalty (Dick and Basu, 1994; Fornell et al., 1996; Hallowell, 1996). Most of these studies, however, have concentrated on products (brands) and to a somewhat lesser extent on services or channel intermediaries. Surprisingly, research on the relationship between store satisfaction and store loyalty has remained limited, both in 
actual number as well as in scope. Yet, in the present environment of increased competition with rapid market entry of new store concepts and formats, the managerial challenge of increasing store loyalty also presents the research challenge of a more in-depth understanding and an empirical estimation of this important type of consumer behavior. There is some evidence that store loyalty may be (positively) related to store image (Osman, 1993). A key aspect is the proactive nature of advocacy. According to McGarry (1995), while a satisfied customer is merely a passive recipient of service, the loyal customer feels a positive connection to the service provider. Loyal customers become active ambassadors for the business.

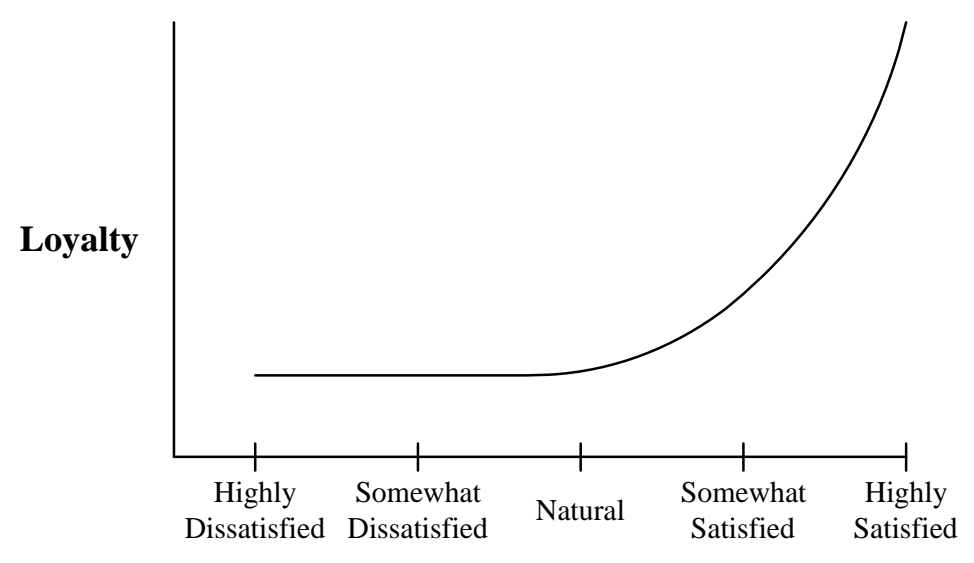

Satisfaction

Figure 3. The relationship between customer satisfaction and loyalty (Tepeci, 1999)

\section{How to assess customer loyalty}

Literature review shows that there exist a few surveys as an approach to assess customer loyalty, comparing with the majority of resources, which focus on loyalty models and frameworks. Table 2 represents a summary of what is extracted from the literature. It is important to note that some of the items are selected from long questionnaires, in which other issues, such as satisfaction, image, etc. were also included. As it is shown, some authors have classified the questions in different categories, depending on different types of loyalty. Considering the questions addressed in Table 2, it seems that different researchers use different sets of questions for their customer loyalty surveys and there is no general agreement on the use of questions.

Table 2. Questions used for the assessment of customer loyalty - A literature review

\begin{tabular}{|c|l|}
\hline Author & \multicolumn{1}{|c|}{ Questions' subjects } \\
\hline & Attitudinal loyalty \\
Chaudhuri and Holbrook, 2001; & - I use heavy equipment from the company I am \\
Oliver, 1997; Pritchard et al., 1999; & evaluating because it is the best choice for me. \\
Sirdeshmukh et al., 2002; Taylor et & - I consider myself to be a loyal patron of the \\
al., 2004 & manufacturer of heavy equipment I am evaluating. \\
& - I am committed to the manufacturer of heavy \\
\hline
\end{tabular}




\begin{tabular}{|c|c|}
\hline Author & Questions' subjects \\
\hline & $\begin{array}{l}\text { equipment I am evaluating. } \\
\text { - In the future, I would be willing to pay a higher price } \\
\text { for heavy equipment from the manufacturer I am } \\
\text { evaluating over competitive offerings. } \\
\text { - I consider the manufacturer I am evaluating my first } \\
\text { choice when buying/leasing heavy equipment. } \\
\text { Behavioral loyalty } \\
\text { - If I had it to do all over again, I'd buy or lease heavy } \\
\text { equipment from a different company. } \\
\text { - I intend to keep buying the equipment of the heavy } \\
\text { equipment manufacturer I am evaluating. } \\
\text { - I would not switch to a competitor, even if I had a } \\
\text { problem with the products/services of the manufacturer } \\
\text { of heavy equipment I am evaluating. } \\
\text { - I intend to purchase heavy equipment from the } \\
\text { manufacturer of the equipment I am evaluating in the } \\
\text { future. }\end{array}$ \\
\hline Foster and Cadogan, 2000 & $\begin{array}{l}\text { Attitudinal loyalty } \\
\text { - I consider XYZ my first choice when buying office } \\
\text { products. } \\
\text { - The XYZ brand has a personality. } \\
\text { - In comparison to other brans I know, the XYZ brand is } \\
\text { growing in popularity } \\
\text { - The XYZ brand is different from competing brands. } \\
\text { Behavioral loyalty } \\
\text { - I intend to do more business with XYZ in the next few } \\
\text { years. } \\
\text { - I intend to do less business with XYZ in the next few } \\
\text { years. } \\
\text { - I intend to take some of my business to a competitor } \\
\text { that offers better prices. } \\
\text { Recommendation behaviours } \\
\text { I say positive things about XYZ to other people. } \\
\text { I recommend XYZ to someone who seeks my advice. } \\
\text { I encourage others to do business with XYZ. } \\
\text { Price loyalty }\end{array}$ \\
\hline
\end{tabular}




\section{Macrothink}

Business Management and Strategy

ISSN 2157-6068

2011, Vol. 2, No. 1: E2

\begin{tabular}{|c|c|}
\hline Author & Questions' subjects \\
\hline & $\begin{array}{l}\text { I would continue to do business with XYZ if its prices } \\
\text { increased somewhat. } \\
\text { I would pay more than competitors' prices for the } \\
\text { benefits I am receiving from XYZ. }\end{array}$ \\
\hline McMullan (2005) & $\begin{array}{l}\text { - If I could do it over again, I'd choose an alternative } \\
\text { ferry operator to XYZ. } \\
\text { - When I see a new ferry service, somewhat different } \\
\text { from the usual, I will try it. } \\
\text { - I usually travel with the same ferry operator. } \\
\text { - I consider myself to be loyal } \\
\text { - If I like a ferry operator, I rarely switch from it, just to } \\
\text { try something different. } \\
\text { - If XYZ is not available, it makes little difference to me } \\
\text { and I travel with an alternative ferry operator. }\end{array}$ \\
\hline Pedersen and Nysveen (2001) & $\begin{array}{l}\text { Cognitive loyalty } \\
\text { - I will keep on using this bank as long as it is profitable } \\
\text { for me. } \\
\text { - I will keep on using this bank as long as it offers the } \\
\text { best interest rates for me. } \\
\text { Affective loyalty } \\
\text { - I have a positive emotional relation to the bank I have } \\
\text { chosen. } \\
\text { - I feel attached to the bank I have chosen. } \\
\text { - In the future I would like to remain a customer of the } \\
\text { bank I have chosen. } \\
\text { - The bank I have chosen has personal meaning to me. } \\
\text { Conative loyalty } \\
\text { - I will recommend the bank I have chosen to persons I } \\
\text { know. } \\
\text { - I think I will keep on using the bank I have chosen for a } \\
\text { long time. } \\
\text { - I intend to remain a customer of the bank I have chosen. }\end{array}$ \\
\hline Soderlund (1998) & $\begin{array}{l}\text { - I would select the same airline again if I was going to } \\
\text { fly another time. } \\
\text { - The next time I fly, I would like to fly with this airline. }\end{array}$ \\
\hline Wong and Sohal (2003) & $\begin{array}{l}\text { Loyalty to contact employee } \\
\text { - Loyalty to a particular employee } \\
\text { - No intention to shop with a particular employee in }\end{array}$ \\
\hline
\end{tabular}




\begin{tabular}{|c|c|}
\hline Author & Questions' subjects \\
\hline & $\begin{array}{l}\text { future* } \\
\text { Loyalty to company } \\
\text { - Say positive things about the retail store to other people } \\
\text { - Recommend the retail store to someone who seeks } \\
\text { advice } \\
\text { - Encourage friends and relatives to shop at the retail } \\
\text { store } \\
\text { - Consider the retail store as first choice in the next few } \\
\text { years } \\
\text { - Make an effort to use the retail store for retail shopping } \\
\text { needs } \\
\text { - Take current business to a competitor that offers more } \\
\text { attractive prices* } \\
\text { - Switch to a competitor when there are problems with } \\
\text { the retail store's service* } \\
\text { - Moving current business to another retail store is just } \\
\text { not worth the effort* } \\
\text { - Deal with the retail store because customer wants to, } \\
\text { not because he/she has to } \\
\text { - Sometimes customers get a feeling of being trapped in } \\
\text { dealing with the retail store* } \\
\text { * Denotes reverse-scored items }\end{array}$ \\
\hline Butcher et al. (2001) & $\begin{array}{l}\text { - Customer thinks of this café as "his" cafe } \\
\text { - It would bother customer if he changes cofe tomorrow } \\
\text { - Customer will strongly recommend the cofe to friends } \\
\text { - If the cofe is busy, customer does not go elsewhere } \\
\text { - This is the customer's favourite café, by a long way }\end{array}$ \\
\hline Wong (2004) & $\begin{array}{l}\text { - Customer says positive things about retail store XYZ to } \\
\text { other people } \\
\text { - Customer recommend retail store XYZ to someone who } \\
\text { seeks his advice } \\
\text { - Customer encourages friends and relatives to shop at } \\
\text { retail store XYZ } \\
\text { - Customer considers retail store XYZ his first choice in } \\
\text { the next few years }\end{array}$ \\
\hline Colwell et al. (2009) & $\begin{array}{l}\text { I believe I have a strong relationship with my bank and } \\
\text { would not leave because of better fees } \\
\text { I believe I have a strong relationship with my bank and } \\
\text { would not leave because of better rates }\end{array}$ \\
\hline
\end{tabular}




\begin{tabular}{|c|c|}
\hline Author & Questions' subjects \\
\hline & $\begin{array}{l}\text { I consider my relationship with my bank as a loyal } \\
\text { relationship between myself and my branch }\end{array}$ \\
\hline Thuy and Hau (2010) & $\begin{array}{l}\text { If I need other types of bank service I will choose this } \\
\text { bank } \\
\text { I will recommend this bank to others who seek my advice } \\
\text { I will continue to use this bank service } \\
\text { I only pay my attention to this bank }\end{array}$ \\
\hline Kassim and Abdullah (2010) & $\begin{array}{l}\text { I will recommend the online organization to other people } \\
\text { (WoM) } \\
\text { I would recommend the organization's website to others } \\
\text { (WoM) } \\
\text { I intend to continue using the online organization (Intent) } \\
\text { I prefer the online organization above others (Intent) }\end{array}$ \\
\hline
\end{tabular}

\section{New methodology: a comprehensive survey of customer loyalty}

In order to propose a comprehensive questionnaire, the authors consider all those items in Table 2 and suggest the following 15 questions to be used for customer loyalty surveys:

1. I use products/services from the company because it is the best choice for me.

2. If I had it to do all over again, I'd buy products/services from this company.

3. I intend to keep buying the products/services from the company.

4. I would continue to do business with the company if its prices increased somewhat.

5. When I see a new product/service, somewhat different from those of the company, I will not try it.

6. I would not switch to a competitor, even if I had a problem with the products/services of the company.

7. If the company is not available, it makes a great difference to me and I will not try an alternative.

8. In comparison to other brands I know, the company is growing in popularity.

9. The company is different from competing brands.

10. I say positive things about the company to other people.

11. I recommend the company to someone who seeks my advice.

12. I have a positive emotional relation to the company I have chosen and I feel attached to it.

13. I am committed to the company.

14. I deal with the company because I want to, not because I have to.

15. I consider myself to be a loyal patron of the company.

\section{Case study and findings}

LG Electronics is one of the leading companies in manufacturing electronic devices. Nowadays LG Electronics is developing its business activities broadly in Iran, especially in 
terms of IT products. MADDIRAN is an exclusive distributor of the IT products of the LG Electronics in Iran. Since few months ago MADDIRAN's top management figured out that some of its customers purchase only once and then switch to other competitors; so they decided to assess their customers' loyalty to MADDIRAN in order to find out their business weaknesses and to know how they could enhance their capabilities, respectively.

The products of MADDIRAN are numerous and only the ODD (Optical Device Drive), is selected as a sample for further analysis.

Table 3. Mean and standard deviation of the answers to the questionnaire

\begin{tabular}{|c|c|c|c|}
\hline No. & Question & Mean & S.D. \\
\hline 1 & $\begin{array}{l}\text { I use products/services from the company because it is } \\
\text { the best choice for me. }\end{array}$ & 4.0952 & 1.18547 \\
\hline 2 & $\begin{array}{l}\text { If I had it to do all over again, I'd buy products/services } \\
\text { from this company. }\end{array}$ & 4.1429 & 0.97709 \\
\hline 3 & $\begin{array}{l}\text { I intend to keep buying the products/services from the } \\
\text { company. }\end{array}$ & 4.0238 & 0.99971 \\
\hline 4 & $\begin{array}{l}\text { I would continue to do business with the company if its } \\
\text { prices increased somewhat. }\end{array}$ & 3.0714 & 1.45490 \\
\hline 5 & $\begin{array}{l}\text { When I see a new product/service, somewhat different } \\
\text { from those of the company, I will not try it. }\end{array}$ & 2.6667 & 1.37338 \\
\hline 6 & $\begin{array}{l}\text { I would not switch to a competitor, even if I had a } \\
\text { problem with the products/services of the company. }\end{array}$ & 3.2857 & 1.43622 \\
\hline 7 & $\begin{array}{l}\text { If the company is not available, it makes a great } \\
\text { difference to me and I will not try an alternative. }\end{array}$ & 3.2143 & 1.37105 \\
\hline 8 & $\begin{array}{l}\text { In comparison to other brands I know, the company is } \\
\text { growing in popularity. }\end{array}$ & 4.0476 & 1.12515 \\
\hline 9 & The company is different from competing brands. & 3.7857 & 1.13773 \\
\hline 10 & I say positive things about the company to other people. & 4.3095 & 1.07040 \\
\hline 11 & $\begin{array}{l}\text { I recommend the company to someone who seeks my } \\
\text { advice. }\end{array}$ & 4.4524 & 0.94230 \\
\hline 12 & $\begin{array}{l}\text { I have a positive emotional relation to the company I } \\
\text { have chosen and I feel attached to it. }\end{array}$ & 4.1667 & 1.10247 \\
\hline 13 & I am committed to the company. & 3.7857 & 1.04848 \\
\hline 14 & $\begin{array}{l}\text { I deal with the company because I want to, not because I } \\
\text { have to. }\end{array}$ & 4.1190 & 1.13056 \\
\hline 15 & I consider myself to be a loyal patron of the company. & 3.6429 & 1.28446 \\
\hline
\end{tabular}

MADDIRAN has an extensive supply chain that contains many dealer channels; also these dealers are divided to different levels, based on their revenues as A+, A and B. These dealers 
sell the goods to two categories; other dealers (B2B) and end-users (B2C). However, only end-users are asked to fill out the questionnaires in order to avoid the ambiguity in the results (Shahin, 2010).

Table 4. 2-tailed one sample $t$ test of the answers to the questionnaire

\begin{tabular}{|c|c|c|c|c|}
\hline No. & Question & Mean & $\mathrm{t}$ & Sig.(2-tailed) \\
\hline 1 & $\begin{array}{l}\text { I use products/services from the company } \\
\text { because it is the best choice for me. }\end{array}$ & 4.0952 & 5.987 & 0.000 \\
\hline 2 & $\begin{array}{l}\text { If I had it to do all over again, I'd buy } \\
\text { products/services from this company. }\end{array}$ & 4.1429 & 7.580 & 0.000 \\
\hline 3 & $\begin{array}{l}\text { I intend to keep buying the products/services } \\
\text { from the company. }\end{array}$ & 4.0238 & 6.637 & 0.000 \\
\hline 4 & $\begin{array}{l}\text { I would continue to do business with the } \\
\text { company if its prices increased somewhat. }\end{array}$ & 3.0714 & 0.318 & 0.752 \\
\hline 5 & $\begin{array}{l}\text { When I see a new product/service, somewhat } \\
\text { different from those of the company, I will not } \\
\text { try it. }\end{array}$ & 2.6667 & -1.573 & 0.123 \\
\hline 6 & $\begin{array}{l}\text { I would not switch to a competitor, even if I } \\
\text { had a problem with the products/services of the } \\
\text { company. }\end{array}$ & 3.2857 & 1.289 & 0.205 \\
\hline 7 & $\begin{array}{l}\text { If the company is not available, it makes a } \\
\text { great difference to me and I will not try an } \\
\text { alternative. }\end{array}$ & 3.2143 & 1.013 & 0.317 \\
\hline 8 & $\begin{array}{l}\text { In comparison to other brands I know, the } \\
\text { company is growing in popularity. }\end{array}$ & 4.0476 & 6.034 & 0.000 \\
\hline 9 & $\begin{array}{l}\text { The company is different from competing } \\
\text { brands. }\end{array}$ & 3.7857 & 4.476 & 0.000 \\
\hline 10 & $\begin{array}{l}\text { I say positive things about the company to } \\
\text { other people. }\end{array}$ & 4.3095 & 7.929 & 0.000 \\
\hline 11 & $\begin{array}{l}\text { I recommend the company to someone who } \\
\text { seeks my advice. }\end{array}$ & 4.4524 & 9.989 & 0.000 \\
\hline 12 & $\begin{array}{l}\text { I have a positive emotional relation to the } \\
\text { company I have chosen and I feel attached to it. }\end{array}$ & 4.1667 & 6.858 & 0.000 \\
\hline 13 & I am committed to the company. & 3.7857 & 4.857 & 0.000 \\
\hline 14 & $\begin{array}{l}\text { I deal with the company because I want to, not } \\
\text { because I have to. }\end{array}$ & 4.1190 & 6.415 & 0.000 \\
\hline 15 & $\begin{array}{l}\text { I consider myself to be a loyal patron of the } \\
\text { company. }\end{array}$ & 3.6429 & 3.244 & 0.002 \\
\hline
\end{tabular}

The proposed questionnaire is distributed to the five important MADDIRAN dealers in major Tehran's IT markets, so whenever an end-user purchases any ODD, dealers request the 


\section{Macrothink}

customer to fill up the questionnaire. The target group of customers is first determined, considering their higher percentage of share in the customers' population under study. Their characteristics included married, men, 25-34 years old, with less than 1000000 Rials (Iran currency) revenue, have diploma, with less than 5 kilometers distance from their home to the company, nongovernmental employed and travel by their own car. 100 questionnaires were first sent by mail to the customers' addresses and totally 42 out of them responded. The mean and standard deviation (S.D.) values of the collected data are presented in Table 3 for the 15 questions.

Also, a two-tailed one sample t test has been used with 0.05 significance level to highlight those answers to the questions, with a value less or more then 3 as the test value. The results are presented in Table 4. A one-way analysis of variance is used to find if there is any difference between the mean values of the answers to the questions. The result is presented in Table 5. The significance level implies that there are some differences between the mean values of answers to the 15 questions.

A correlation test has been done to find if the questions are interrelated. The results are presented in Table 6.

Table 5. One-way analysis of variance

\begin{tabular}{|c|c|c|c|c|c|}
\hline & $\begin{array}{c}\text { Sum of } \\
\text { squares }\end{array}$ & df & Mean square & F & Sig. \\
\hline Between groups & 154.689 & 14 & 11.049 & 7.839 & 0.000 \\
\hline Within groups & 866.810 & 615 & 1.409 & & \\
\hline Total & 1021.498 & 629 & & & \\
\hline
\end{tabular}




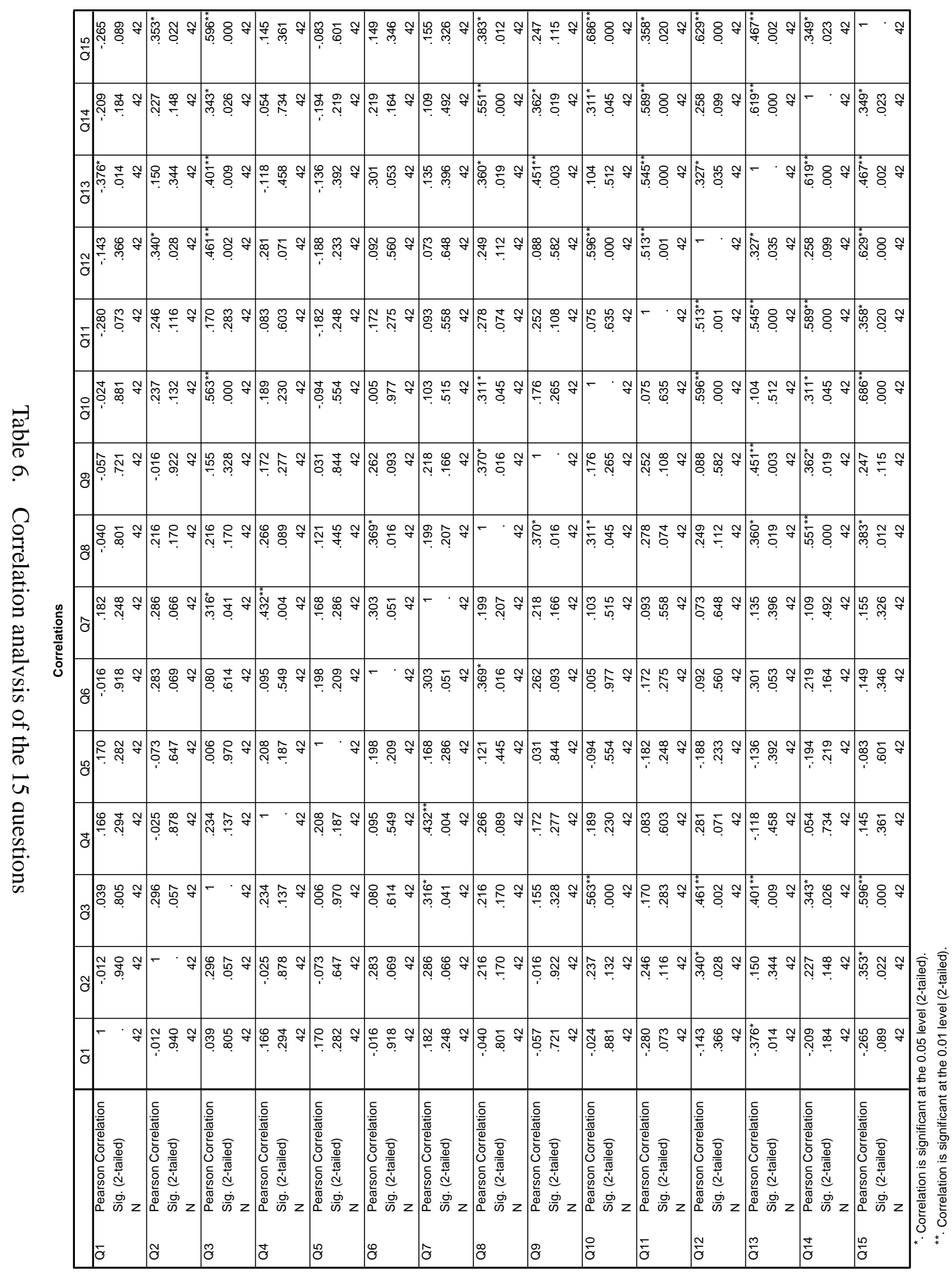




\section{Discussion}

According to Table 3, the highest and the lowest mean values of responses are related to questions 11 and 5, respectively. In other words, although customers recommend the company to others, if they see new products/services different from those of the company, then they might try it. According to Figure 2, it could be argued that the behavior of those customers could be classified as spurious loyally, which represents a low relative attitude, with high repeat patronage. The mean value of the responses to question 15, i.e. 3.65, which is relatively medium, supports the former outcome and points out that the customers are not totally loyal.

Considering the results of the two-tailed one sample t test in Table 4, it is found that 10 out of the 15 questions have responses values more than the median, i.e. 3; one has a value less than the median and four of them have a value around the median.

An important note here is that standard deviations of questions 4, 5, 6 and 7 are relatively more than the others (Table 3) and those four questions are exactly the questions, which have response values around the median (Table 4); therefore, it could be concluded that having a response value near the median might be due to the high standard deviation, which in turn could be an outcome of the differences between customers. Although initial customer segmentation was done before the analysis and a target group was defined, there still seems to be other characteristics, e.g. demographic characteristics to study and respectively to further segmentation of the customers (Shahin and Chan, 2006).

The results of the one-way analysis of variance imply that there exists difference between the mean values of responses to questions (Table 5). In order to find the place of difference, Tukey HSD and Waller-Duncan test are used and the analysis provides similar results to what has been done earlier in the one sample t test, i.e. question 1 with a mean value less than 3 ; questions 2, 3, 4, 5 with a mean value around 3; and other questions with mean values more than 3.

The correlation analysis provides important outcomes. It is assumed that the Pearson correlation value of 0.5 and over needs to be considered in further analysis. Therefore, the corresponding questions are addressed in Table 7.

According to Table 7, it could be argued that for instance, if someone intend to keep buying the product/ services from the company (Q3), then there is \%56.3 probability that he/she says positive things about the company to others; or for instance, if 100 customers say positive things about the company to others, then it is possible that 69 of them could be considered as loyal customers. The applicability of Table 7 is not limited to the above discussion. The results could also be used for reducing number of questions in cases that the questionnaire survey is hard to manage, due to the large number of questions.

As it was mentioned in Table 7, the correlation values of 0.5 and over were only represented. In Table 8 however, the absolute value of the significant correlation at 0.05 level (*) and at 0.01 level $\left({ }^{* *}\right)$ are presented. As it is shown, questions 13,14 and 15 have significant 
correlations with almost half of the questions; therefore the last 3 questions in the questionnaire are very important and should always be included in the customer loyalty questionnaires.

Table 7. Questions with correlation value of 0.5 and over

\begin{tabular}{|c|c|c|c|}
\hline Question $(\mathrm{Q})$ & Correlated with Q & Correlation value & Sig. (2-tailed) \\
\hline 3 & 10 & 0.563 & 0.000 \\
\hline 3 & 15 & 0.596 & 0.000 \\
\hline 8 & 14 & 0.551 & 0.000 \\
\hline 10 & 12 & 0.596 & 0.000 \\
\hline 10 & 15 & 0.686 & 0.000 \\
\hline 11 & 12 & 0.513 & 0.001 \\
\hline 11 & 13 & 0.545 & 0.000 \\
\hline 11 & 14 & 0.589 & 0.000 \\
\hline 12 & 15 & 0.629 & 0.000 \\
\hline
\end{tabular}

Table 8. Significant correlation values

\begin{tabular}{|c|l|c|}
\hline Question & Correlated question(s) & $\begin{array}{c}\text { Number of correlated } \\
\text { questions }\end{array}$ \\
\hline 1 & $13^{*}$ & 1 \\
\hline 2 & $12^{*}-15^{*}$ & 2 \\
\hline 3 & $7^{*}-10^{* *}-12^{* *}-13^{* *}-14^{*}-15^{* *}$ & 6 \\
\hline 4 & $7^{*}$ & 1 \\
\hline 5 & - & - \\
\hline 6 & $8^{*}$ & 1 \\
\hline 7 & $3^{*}-4^{* *}$ & 2 \\
\hline 8 & $6^{*}-9^{*}-10^{*}-13^{*}-14^{* *}-15^{*}$ & 6 \\
\hline 9 & $8^{*}-13^{* *}-14^{*}$ & 3 \\
\hline 10 & $3^{* *}-8^{*}-12^{* *}-14^{*}-15^{* *}$ & 5 \\
\hline 11 & $12^{* *}-13^{* *}-14^{* *}-15^{*}$ & 4 \\
\hline 12 & $2^{*}-3^{* *}-10^{* *}-11^{* *}-13^{*}-15^{* *}$ & 6 \\
\hline 13 & $1^{*}-3^{* *}-8^{*}-9^{* *}-11^{* *}-12^{*}-14^{* *}-15^{* *}$ & 8 \\
\hline 14 & $3^{*}-8^{* *}-9^{*}-10^{*}-11^{* *}-13^{* *}-15^{*}$ & 8 \\
\hline 15 & $2^{*}-3^{* *}-8^{*}-10^{* *}-11^{*}-12^{* *}-13^{* *}-14^{*}$ & 7 \\
\hline
\end{tabular}

* correlation is significant at the 0.05 level (2-tailed)

** correlation is significant at the 0.01 level (2-tailed)

It is important to note that question 5 has no significant correlation with other questions. Perhaps the low correlation value is because of its relatively high standard deviation (1.38) due to the possible ambiguity in customers' responses.

The data in Table 8 is somehow useful for instance in regression, when each of the 15 
questions is considered as dependent and the correspondent questions with which they have significant correlations are considered as independent.

\section{Conclusions}

Based on a literature review, this study proposed a comprehensive questionnaire for customer loyalty assessment. The research examined the questionnaire in MADDIRAN, the distributor of LG Electronics in Iran. The analysis also examined how the questions are inter-correlated. The findings both complement and extend previous research.

The results imply that almost all of the responses to the questionnaire had a mean value higher than the median (3), except for question 5 with a lower value in which, the possibility of switching customers to other competitors was studied. It was also found that some of the questions had meaningful inter-correlations. The last three questions (i.e., commitment of customers to the company, intent of customers to deal with the company, and the belief of being loyal to the company by the customers were found to have significant correlations with almost half of the questions.

The results of this study have direct implications for service marketing practitioners. The results imply the need for a service firm to strategically leverage on the key antecedents of customer loyalty in its pursuit of customer retention and long-term profitability. Service Marketing practitioners and academicians will benefit from this study in that it tried to propose a comprehensive questionnaire for the assessment of customer loyalty. The loyalty scale allows managers to identify the most important aspects of their service in relation to the development of their customers' loyalty.

It is acknowledged that the survey design has limitations with respect to causal inferences and the use of standardized questions limits respondent comments. While Likert scales are popular in marketing research, they also have weaknesses and multi-item scales tested in the same instrument may produce overstated correlations.

An important limitation of the study concerns the fact that the customers' anticipated behaviors were only measured, not their actual behavior. A longitudinal research design would be useful in this respect since customer loyalty could be changed over time and changes in these pertinent variables could be correlated with actual behaviors. As Boles et al. (1997) note, unless actual behavior is measured, we cannot be certain that reported intentions to behave in a loyal way will be translated into actual behaviors.

In this research only one product of the MADDIRAN Co. was examined; also, only one target group of customers considering their demographic characteristics was selected for the analysis. As a consequence, the generalizability of the findings to other service/ products/ firms/ groups of customers is limited. As Slater (1995) notes, while the generalizability of studies undertaken in a single firm must be viewed with some skepticism, the results are likely to have increased internal validity. Clearly, future research which provides more information on the external validity of this study would be most welcome. This may include 
for example a replication of this study using multiple services/ products / firms within a firm / industry or perhaps a multi-industry replication.

This study enhances the knowledge and capabilities of managers and decision makers in order to be better equipped to consider pros and cons of customer relationship programs. Researchers could consider testing the relationships investigated in this research in different service contexts with different methods.

\section{References}

Aaker, D.A. (1991a). Brand Equity. New York, NY: The Free Press.

Aaker, D.A. (1991b). Managing Brand Equity: Capitalizing on the Value of Brand Name. New York, NY: The Free Press.

Anderson, E. \& Sullivan, M.W. (1993). The antecedents and consequences of customer satisfaction for firms. Marketing Science, 12(2), 125-143.

Andreassen, T.W. \& Lindestad, B. (1998). Customer loyalty and complex services: the impact of corporate image on quality, customer satisfaction and loyalty for customers with varying degrees of service expertise. International Journal of Service Industry Management, 9(1), 7-23.

Andreassen, T.W. (1995). Small, high cost countries strategy for attracting MNC's global investments. The International Journal of Public Sector Management, 8(3), 24-38.

Ball, D., Coelho, P.S. \& Machas, A. (2004). The role of communication and trust in explaining customer loyalty: An extension to the ECSI model. European Journal of Marketing, 38(9/10), 1272-1293.

Barnes, J.G. (1997). Closeness, strength, and satisfaction: examining the nature of relationships between providers of financial services and their retail customers. Psychology \& Marketing, 14(8), 765-790.

Baumann, C., Elliott, G. \& Hamin, H. (2011). Modelling customer loyalty in financial services - a hybrid of formative and reflective constructs. International Journal of Bank Marketing, 29(3), 247-267.

Bennett, R. (2001). A study of brand loyalty in the business-to-business services sector. University of Queensland, Brisbane: School of Management, p. 258.

Bettencourt, L.A. \& Brown, S.W. (1997). Contract employees: relationships among workplace fairness, job satisfaction and prosaically service behaviors. Journal of Retailing, 73(1), 39-61.

Blodgett, J.G., Hill, D.J. \& Tax, S.S. (1997). The effects of distributive, procedural, and interactional justice on post complaint behavior. Journal of Retailing, 73(2), 185-210.

Boles, J.S., Barksdale, H.C. Jr. \& Johnson, J.T. (1997). Business relationships; an 
examination of the effects of buyer-supplier relationships on customer retention and willingness to refer and recommend. Journal of Business \& Industrial Marketing, 12(3/4), 248-258.

Butcher, K., Sparks, B. \& O'Callaghan, F. (2001). Evaluative and relational influences on service loyalty. International Journal of Service Industry Management, 12(4), 310-327.

Chaudhuri, A. \& Holbrook, M.B. (2001). The chain of effects from brand trust and brand affect to brand performance: the role of brand loyalty. Journal of Marketing, 65(2), 81-93.

Colwell, S., Hogarth-Scott, A., Jiang, D. \& Joshi, A. (2009). Effects of organizational and serviceperson orientation on customer loyalty. Management Decision, 47(10), 1489-1513.

Cunningham, R.M. (1956). Brand loyalty - what, where, how much? Harvard Business Review, 34(1), 116-128.

De Ruyter, K., Wetzels, M. \& Bloemer, J. (1998). On the relationship between perceived service quality, service quality and switching costs. International Journal of Service Industry Management, 9(5), 436-453.

Dick, A.S. \& Basu, K. (1994). Customer loyalty: Toward and integrated conceptual framework. Journal of the Academy of Marketing Science, 22(2), 99-113.

Divett, M., Crittenden, N. \& Henderson, R. (2003). Actively influencing consumer loyalty. Journal of Consumer Marketing, 20(2), 109-126.

Fornell, C. (1992). A national customer satisfaction barometer: the Swedish experience. Journal of Marketing Research, 56(1), 6-21.

Fornell, C., Johnson, M.D., Anderson, E.W., Cha, J. \& Bryant, B.E. (1996). The American customer satisfaction index: nature, purpose, and findings. Journal of Marketing, 60(4), 7-18.

Foster, B.D. \& Cadogan, J.W. (2000). Relationship selling and customer loyalty: an empirical investigation. Marketing Intelligence \& Planning, 18(4), 185-199.

Gee, R., Coates, G. \& Nicholson, M. (2008). Understanding and profitably managing customer loyalty. Marketing Intelligence \& Planning, 26(4), 359-374.

Griffin, J. (1995). Customer loyalty. San Francisco, CA: Jossey-Bass Publishers.

Guest, L. (1955). Brand loyalty: twelve years later. Journal of Applied Psychology, 39(6), 405-408.

Gwinner, K.P., Gremler, D.D. \& Bitner, M.J. (1998). Relational benefits in services industries: the customer's perspective. Journal of the Academy of Marketing Science, 26(2), 101-114.

Hallowell, R. (1996). The relationships of customer satisfaction, customer loyalty, and profitability: an empirical study. International Journal of Service Industry Management, 7(4), 27-42. 
Hawkes, P. (1994). Building brand loyalty and commitment. The Journal of Brand Management, 1(6), 337-347.

Ho, R., Huang, L., Huang, S., Lee, T., Rosten, A. \& Tang, C.S. (2009). An approach to develop effective customer loyalty programs: The VIP program at T\&T Supermarkets Inc., Managing Service Quality, 19(6), 702- 720.

Jacoby, J. \& Chestnut, R. (1978). Brand Loyalty Measurement and Management., New York, NY: John Wiley \& Sons.

Javalgi, R.G. \& Moberg, Ch.R. (1997). Service loyalty: Implications for service providers. The Journal of Services Marketing, 11(3), 165-179.

Kassim, N. \& Abdullah, N.A. (2010). The effect of perceived service quality dimensions on customer satisfaction, trust, and loyalty in e-commerce settings - A cross cultural analysis. Asia Pacific Journal of Marketing \& Logistics, 22(3), 351-371.

Keller, K.L. (1993). Conceptualizing, measuring, and managing customer-based brand equity. Journal of Marketing, 57(1), 1-22.

Kingstrom, P.O. (1983). Patient ties to ambulatory care providers: the concept of provider Loyalty. Journal of Healthcare Marketing, 3(2), 27-34.

Lach, J. (2000). Redeeming qualities. American Demographics, 22(5), 36-38.

Lemmink, J. \& Mattsson, J. (1998). Warmth during non-productive retail encounters: the hidden side of productivity. International Journal of Research in Marketing, 15(5), 506-517.

Loveman, G.W. (1998). Employee satisfaction, customer loyalty, and financial performance. Journal of Service Research, 1(1), 18-31.

Mandhachitara, R. \& Poolthong, Y. (2011). A model of customer loyalty and corporate social responsibility. Journal of Services Marketing, 25(2), 122-133.

McGarry, D.E. (1995). The road to customer loyalty. Canadian Business Review, 22(1), 35-36.

McMullan, R. (2005). A multiple-item scale for measuring customer loyalty development. Journal of Services Marketing, 19(7), 470-481.

Oliver, R. (1997). Satisfaction: A Behavioral Perspective on the Consumer. Boston, MA: Irwin/McGraw-Hill.

Oliver, R.L. (1999). Whence customer loyalty. Journal of Marketing, 63(4), 33-44.

Osman, M.Z. (1993). A conceptual model of retail image influences on loyalty patronage behavior. The International Review of Retail, Distribution \& Consumer Research. 31, 149-166.

Pedersen, P.E. \& Nysveen, H. (2001). Shopbot banking: an exploratory study of customer 
loyalty effects. International Journal of Bank Marketing, 19(4), 146-155.

Pessemier, E.A. (1960). An experimental method for estimating demand. The Journal of Business, 33(1), 373-383.

Price, L.L. \& Arnould, E.J. (1999). Commercial friendships: service provider-client relationships in context. Journal of Marketing, 63(4), 38-65.

Pritchard, M.P., Havitz, M.E. \& Howard, D.R. (1999). Analyzing the commitment-loyalty links in service contexts. Journal of the Academy of Marketing Science, 27(3), 333-348.

Raj, S.P. (1985). Striking a balance between brand 'popularity' and brand loyalty. Journal of Marketing, 49(1), 53-59.

Ramanathan, U. \& Ramanathan, R. (2011). Guests' perceptions on factors influencing customer loyalty - an analysis for UK hotels. International Journal of Contemporary Hospitality Management, 23(1), 7-25.

Reichheld, F.F. (1996). The Loyalty Effect. Boston, MA: Harvard Business School Press.

Rowley, J. \& Dawes, J. (1999). Customer loyalty - a relevant concept for libraries? Library Management, 20(6), 345-351.

Rundle-thiele, Sh. \& Mackay, M.M. (2001). Assessing the performance of brand loyalty measures. Journal of Services Marketing, 15(7), 529-546.

Rundle-Thiele, Sh. (2005). Exploring loyal qualities: assessing survey-based loyalty measures. Journal of Services Marketing, 19(7), 492-500.

Shahin, A. \& Chan, J.F.L. (2006). Customer Requirements Segmentation (CRS): A Prerequisite Technique for Quality Function Deployment (QFD). Total Quality Management \& Business Excellence, 17(5), 567-587.

Shahin, A. (2006). SERVQUAL and model of service quality gaps: A framework for determining and prioritizing critical factors in delivering quality services. in Partha Sarathy V. (ed). Service quality - An introduction, Andhra Pradesh: ICFAI University Press, 117-131.

Shahin, A. (2010). SSCM: Service Supply Chain Management. International Journal of Logistics Systems \& Management, 6(1), 60-75.

Sharp, B., Rundle-Thiele, S. \& Dawes, J. (1997). In Australia New Zealand Marketing Educators. In Reed, P., Luxton, S. \& Shaw, M.R. (eds). Conference 97. Vol. 3. Monash University, Melbourne: Department of Marketing, 1283-1293.

Sirdeshmukh, D., Singh, J. \& Sabol, B. (2002). Consumer trust, value, and loyalty in relational exchanges. Journal of Marketing, 66(1), 15-37.

Slater, S.F. (1995). Issues in conducting marketing strategy research. Journal of Strategic Marketing, 3(4), 257-270. 


\section{Macrothink}

Business Management and Strategy ISSN 2157-6068 2011, Vol. 2, No. 1: E2

Smith, D.C. \& Whan Park, C. (1992). The Effects of Brand Extensions on Market Share and Advertising Efficiency. Journal of Marketing Research, 29(3), 296-313.

Soderlund, M. (1998). Customer satisfaction and its consequences on customer behaviour revisited the impact of different levels of satisfaction on word-of-mouth, feedback to the supplier and loyalty. International Journal of Service Industry Management, 9(2), 169-188.

Soderlund, M. (2006). Measuring customer loyalty with multi-item scales. International Journal of Service Industry Management, 17(1), 76-98.

Stum, D.L. \& Thiry. A. (1991). Building customer loyalty. Training \& Development Journal, 45(4), 34-36.

Taylor, S.A., Celuch, K. \& Goodwin, S. (2004). The importance of brand equity to customer loyalty, Journal of Product \& Brand Management, 13(4), 217-227.

Tepeci, M. (1999). Increasing brand loyalty in the hospitality industry. International Journal of Contemporary Hospitality Management, 11(5), 223-229.

Thuy, P.N. \& Hau, L.N. (2010). Service personal values and customer loyalty A study of banking services in a transitional economy. International Journal of Bank Marketing, 28(6), 465-478.

Uncles, M.D., Dowling, G.R. \& Hammond, K. (2003). Customer loyalty and customer loyalty programs. Journal of consumer Marketing, 20(4), 294-316.

Wong, A. \& Sohal, A. (2003). Service quality and customer loyalty perspectives on two levels of retail relationships. Journal of Services Marketing, 17(5), 495-513.

Wong, A. (2004). The role of emotional satisfaction in service encounters. Managing Service Quality, 14(5), 365-376.

Zeithaml, V., Berry, L. \& Parasuraman, A. (1996). The behavioral consequences of service quality. Journal of Marketing, 60(2), 31-46. 